\title{
WORKABILITY AND MACHINERY PERFORMANCE FOR WHEAT HARVESTING
}

\author{
Ismail, Z.E. ${ }^{1}$ and A.E. Abdel-Mageed ${ }^{2}$
}

\begin{abstract}
The present study was carried out to evaluate three harvesting systems based on machine and workability of the operations performance for wheat production. Wheat is the most unique of all grain crops in its adaptability to harvested in different method. Three methods under study are evaluated, namely: green combine-bagger or tank (first method; reaper + thresher (second method) and the manual (third method). The evaluation of harvesting systems involves a number of modeling approaches and the models fall into: The first is evaluating machine performance by measuring machine capacity and the labour requirement. The second parameter is workability, which is calculated measuring the two mean factors, mainly, the length of harvesting period and potential harvesting hours. The third is economical evolution which is dun calculating fixed costs, operating costs and optimal harvesting capacity. It is important that unproductive work be minimized. Therefore, Optimum harvesting operations as well as good systems is needed to minimize the cost and obtain maximum profits. The required of the labour number for three systems under studies were 5; 2; 15 and 23 labour per harvesting systems for combine with tank, combine with bagger, "reaper + thresher" and "manual + thresher" systems respectively. Also, the total manual energy required " $\mathrm{kW} . \mathrm{h} / \mathrm{ton}^{\prime}$ recorded $0.8 \mathrm{~kW} . \mathrm{h} / \mathrm{fed}$ while; it was about $6.73 \mathrm{~kW} . \mathrm{h} /$ fed for the manual system. Regarding to the purchase price of combine machine, the power per unite area is very small but the inertia cost is very height.
\end{abstract}

\section{INTRODUCTION}

abour and machinery dominate all other cost categories in arable
farming and much is to be gained by adapting and balancing
resources according to the actual needs arising from farm size, crop plan, etc. In this situation, wheat harvesting is a good example of

1- Prof. of Power technology and farm machinery, Ag. Eng., Dept., Mansoura Un., Egypt. Email: Ismailze221@mans.edu.eg

2- Assis. Res. Ag. Eng., Ag. Eng. Res. Inst. (AEnRI) Ag. Res. Center. 
compromise machinery management, highlighting the inherent complex evaluations. Ismail et al. (2009) indicted that the harvesting costs make up $35 \%$ of the total machinery costs. This emphasizes the need for developing robust methods for choosing the optimal harvesting equipment.

The analysis and prediction of agricultural machinery performance are important aspects of all machinery management efforts (Witney, 1995). Abdel-Mageed et al. (1987) mentioned that almost every agricultural operation required for successful crop production must be timely. Untimely completion of any of these operations will cause a substantial loss of yield and quality, which ultimately will affect the farm's income. This loss is termed "timeliness penalty" or "timeliness cost". Edward and Boehye (1980) developed a simulation model to estimate net machinery costs for corn-soybean farms. They found that increasing farm size (both area of crops and labour supply) increased the size of the least. Cost machinery sets to the greatest degree and decreasing the proportion of labour and field hours available per land unit had the next most significant (positive) effect on the least.

Although there are numerous data depicting the net capacity of combines, on-farm surveys show that the actual field performance differs considerably. When field operations, such as harvesting, are analyzed the primary activity is that of carrying out the operation. Although some nonproductive activities (turning time, adjustment time, etc.) are unavoidable, the goal is to minimize the sum of these nonproductive activities, as they may total as much as $40 \%$ (Henrichsmeyer et al., 1995). Elrick (1982) stated that the slowest $10 \%$ of combine operators are only half as fast as the fastest $10 \%$ over the whole harvest season when the same combine model is used.

One of the most crucial pieces of information for determining machinery sizes is the number of potential field working hours (e.g., Audsley, 1984 and Ekman, 2000) contained within the term workability. Previous working-days criteria for combine harvesting include threshold values for past amounts of rainfall (Audsley and Boyce, 1974) and the combination of rainfall thresholds and algorithms for grain moisture content (e.g., Philips and O'Callaghan, 1974 and Atzema, 1994). Explanatory models suggest 
that prediction using grain moisture content, in conjunction with meteorological data, is the most promising working-day criterion, especially if operates on an hourly basis (e.g., Goense, 1987; Atzema, 1990). Previous efforts have included a number of modeling approaches to support farm machinery selection. The approaches involved simulation (e.g., Soerensen (2003); Srivastava et al. (2006); Nilsson (1987) De Toro and Hansson (2004) and Witney (1995), linear programming techniques (e.g., Nilsson, 1972; Bender et al., 1990; Jannot and Cairol, 1994; Parmar et al., 1996), or a combination of these modeling and solution techniques (Tsai et al., 1987).

The approach described here involves an analysis and modeling of the harvesting operation based on a level of aggregation consistent with the accessible data related to machinery performance and workability. The machine performance is based on detailed farm-specific task time models and the workability is based on calculate the length of harvesting period and potential harvesting hours models.

\section{METHODOLOGY}

Three different systems were used to harvesting wheat croup, namely the Combine machine model Deutz Fahr 660, with two storage types (tank and bagger), Reaper machine (ITT-CRS) to cutting the crop and threshed using thresher machine model HMT/1987 and finally manual (harvester+ thresher) system. The specification of the used machines tabulates in table (1). Under all calculations the specification of tractors is found in the table (2). The evaluation of harvesting systems involves a number of modeling approaches and the models fall into the following categories:-

\section{Machine performance}

The machine performances for all different types under study were evaluated measuring machine capacity and the labour requirement.

\section{Workability}

The second parameter is workability, which is calculated measuring the two mean factors, mainly, the length of harvesting period and potential harvesting hours.

\section{Economics}


The economic evolution is dun calculating fixed costs, operating costs and optimal harvesting capacity

\section{The overall field capacity}

The total time for each machine used in the harvesting process was divided into time elements. These time elements included operation time (effective field time, turning time, unloading, etc.), ancillary time (adjustments, repairs, disturbances due to crop or soil, relaxation allowance, etc.), waiting time and preparation time. Then the overall field capacity $(\mathrm{OC}, \mathrm{fed} / \mathrm{h})$ is calculated from the following equation:-

$$
\mathrm{OC}=\frac{60}{\left[\frac{\mathrm{h} \times 252}{\mathrm{v} \times \mathrm{e}}+\frac{\mathrm{p} \times \mathrm{b} \times \mathrm{n}}{2 \mathrm{e}}+\mathrm{k}+[(\mathrm{s} \times \mathrm{h}) \times 1 / \mathrm{h}]+\left(\frac{\mathrm{m} \times \mathrm{u} \times 1000}{1}+(\mathrm{u} \times \mathrm{c})\right)\right] \times(1+\mathrm{q})}
$$

Where;

$\mathrm{h}$ is the size of field (fed),

$\mathrm{v}$ is the working speed $(\mathrm{km} / \mathrm{h})$,

e is the effective working width (m),

$\mathrm{p}$ is the time for turning (min),

$\mathrm{b}$ is the field width $(\mathrm{m})$,

$\mathrm{n}$ is the number of turnings,

$\mathrm{k}$ is the turnings on treatment of headland ( $\mathrm{min}$ ),

$\mathrm{s}$ the time of adjustments, control, tending of machine, etc. (min),

$\mathrm{m}$ is the preparation for unloading $(\mathrm{min})$,

$\mathrm{u}$ is the expected yield (ton/fed),

1 is the net tank size $(\mathrm{kg})$,

$\mathrm{c}$ is the net unit of unloading time ( $\mathrm{min})$, and

$\mathrm{q}$ is an assessed rest allowance time amounting to 5\% additional time (min)

Most statistical information on combines presents the combine net capacity in terms of the harvesting speeds (Elrick, 1982; Lundin and Claesson, 1985).

\section{The wheat harvesting efficiency}

Based on the developed model, the harvester performance in terms of theoretical and gross capacities was estimated. The theoretical capacity was determined as the capacity when driving in the swath with full header width and average harvesting speed at standard loss levels $(<2 \%)$. 
Table (1): Specification of harvesting machines

\begin{tabular}{|l|l|l|l|}
\multicolumn{1}{|c|}{ Machines Items } & \multicolumn{1}{c|}{ Reaper } & \multicolumn{1}{c|}{ Thresher } & $\begin{array}{l}\text { Multi-purpose } \\
\text { combine }\end{array}$ \\
\hline Model & $1986 \mathrm{ITT} / \mathrm{CRS}$ & HMT/1987 & Deutz Fahr 660 \\
\hline Working width & $1.5 \mathrm{~m}$ & $2.0 \mathrm{~m}$ & $2.0 \mathrm{~m}$ \\
\hline Width & $2430 \mathrm{~mm}$ & $2090 \mathrm{~mm}$ & $3.48 \mathrm{~m}$ \\
\hline Length & $2982 \mathrm{~mm}$ & $2300 \mathrm{~mm}$ & $8.16 \mathrm{~m}$ \\
\hline Height & $720 \mathrm{~mm}$ & $2350 \mathrm{~mm}$ & $3.58 \mathrm{~m}$ \\
\hline Weight & $200 \mathrm{~kg}$ & $1445 \mathrm{~kg}$ & $5100 \mathrm{~kg}$ \\
\hline Source of power & $\begin{array}{l}\text { Tractor PTO } \\
\text { shaft }\end{array}$ & $\begin{array}{l}\text { Tractor PTO } \\
\text { shaft }\end{array}$ & $\begin{array}{l}4 \\
\text { engine }\end{array}$ \\
\hline Source of manufacturer & Local & Turkish & Germany \\
\hline Max. Power output & ---- & ---- & $63 \mathrm{hp}$ \\
\hline Drum speed & & $800 \mathrm{rpm}$ & \\
\hline
\end{tabular}

Overall, the gross capacity takes into account the complete operational cycle, including all turnings, unloading, occasional stops, rest allowances, etc., as identified by the on-farm measurements.

Table (2): The tractor specifications

\begin{tabular}{|c|c|}
\hline Items & Specifications \\
\hline Country paternity & Romanian \\
\hline $\begin{array}{l}\text { Power: at PTO (factory observed at } \\
2100 \mathrm{rpm} \text { ) }\end{array}$ & (76HP) \\
\hline Type & Diesel \\
\hline Cylinders: & 4 In Line \\
\hline Slow idle speed & $850+50 \mathrm{rpm}$ \\
\hline High idle speed & $2275+50 \mathrm{rpm}$ \\
\hline Bore and stroke & $115.9 \times 120.6 \mathrm{~mm}$. \\
\hline $\begin{array}{l}\text { Compression ratio } \\
\text { Displacement: }\end{array}$ & $\begin{array}{l}15.8: 1.0 \\
7.6 \mathrm{~L}\end{array}$ \\
\hline Firing order & $1-3-2-4$ \\
\hline Valve Clearance Intake \& Exhaust & $0.38 \mathrm{~mm} 0.51 \mathrm{~mm}$. \\
\hline Lubrication system & Full pressure - full flow filtration \\
\hline Mass & $3930 \mathrm{~kg}$ \\
\hline Top of steering wheel & $2929 \mathrm{~mm}$ \\
\hline \multicolumn{2}{|l|}{ Hydraulic system } \\
\hline Maximum pressure & 200 bar \\
\hline Electrical system: & Type: 12 volt negative ground \\
\hline $\begin{array}{l}\text { Batteries } \\
\text { Alternator }\end{array}$ & $\begin{array}{l}12 \text { volt in parallel } \\
140 \text { Amp. }\end{array}$ \\
\hline Gear selections: & 4 forward, 1. Reverse 2. Methods \\
\hline
\end{tabular}

Summarizing, the efficiency of the harvesting operation is expressed by the field efficiency factor $(F E)$. This factor, denoting the fraction of the actual 
operational combining time spent on productive work, was estimated as the ratio of the gross capacity to the theoretical capacity.

\section{Energy requirements}

The power consumption (Er, $\mathrm{kW}$ ) for different systems were calculated according to the following equation (Hunt- 1995)

$$
\mathrm{Er}=\mathrm{Fc}\left(\frac{1}{60 \times 60}\right) \mathrm{P} \times \mathrm{LCV} \times 427 \times \eta_{t h} \times \eta_{m} \times \frac{1}{75} \times \frac{1}{1.36} ; \quad \mathrm{kW}
$$

Where:

$$
\begin{aligned}
& \mathrm{Fc}=\text { the fuel consumption } \mathrm{L} / \mathrm{h} \\
& \text { P.F }=\text { the fuel density, } \quad \mathrm{kg} / \mathrm{L} \text { (for solar }=0.85 \text { ) } \\
& \text { L.C.V. = the lowest calorific value of fuel }\left(\mathrm{k}_{\mathrm{ca}} / \mathrm{kg}\right) \text { average L.C.V of } \\
& \text { diesel is } 11000 \mathrm{k}_{\mathrm{cal}} / \mathrm{kg} \text { ) } \\
& \eta_{\mathrm{th}}=\text { the thermal efficiency of the engine, (considered to be about } \\
& 35 \% \text { for diesel engine) } \\
& 427=\text { thermo-mechanical equivalent, } \mathrm{kg} \cdot \mathrm{m} / \mathrm{kcal} \\
& \eta_{\mathrm{m}}=\text { the mechanical efficiency of the engine, (considered to be } 80 \% \\
& \text { for diesel engine) }
\end{aligned}
$$

So, the energy can be calculated as following:

$$
\text { Energy requirement }=\frac{\text { Engine power }(\mathrm{kW})}{\text { Production }(\mathrm{kg} / \mathrm{h})} \quad \mathrm{kW} \cdot \mathrm{h} / \mathrm{kg}
$$

Manual energy: the manual energy $\left(\mathrm{E}_{\mathrm{H}}\right)$ per feddan was calculated by considering the power of one labour about $0.1 \mathrm{hp}$, Chancellor (1981).

$$
\mathrm{E}_{\mathrm{H}}=\frac{0.1 \times 0.74 \times \mathrm{N}_{\mathrm{L}}}{\mathrm{P}_{\mathrm{a}}}=\frac{\mathrm{N}_{\mathrm{L}}}{\mathrm{P}_{\mathrm{a}}} \times 0.0746 \quad \mathrm{~kW} . \mathrm{h} / \mathrm{fed}
$$

Where:

$$
\begin{aligned}
& 0.1=\text { hp of agricultural labour (hp/man) } \\
& \mathrm{NL}=\text { number of labour } \\
& \mathrm{Pa}=\text { actual productivity (fed/h) } \\
& 0.746=\text { co-efficiently per conversion from hp to } \mathrm{kW} .
\end{aligned}
$$

\section{The wheat harvesting machinery costs}

The current economic model focuses on the system costs, including both machinery costs (fixed and variable) as well as repair and maintenance 
costs. The model is derived from theories described by Nilson (1972), Have (1991) and Hunt (1995), and expresses the total yearly fixed and variable costs as a function of machine capacity:

$$
\mathrm{C}=\left[\psi \times \rho \times \theta+\frac{\mathrm{A} \times \mathrm{U}}{\theta \times \mathrm{FE}} \times(\mathrm{r} \times \rho \times \theta+\mathrm{L}+\delta \times \theta)\right] / \operatorname{Pr}
$$

Where;

$\mathrm{C}$ is the total yearly costs (LE/ton),

$\psi$ is a factor expressing depreciation and interest as a fraction of the purchase price, (1/year)

$\rho$ is the purchase price per unit capacity (LE.h/ton),

$\theta$ is the machine capacity (ton/h),

A is the treated seasonal area (fed/year),

$\mathrm{U}$ is the expected crop yield (ton/fed),

FE is the field efficiency expressing the ratio between gross and theoretical capacity,

$\mathrm{r}$ is a factor expressing repair and maintenance costs as a fraction of purchase price (table 3),

$\delta$ is the fuel costs proportional to the capacity $(\mathrm{LE} / \mathrm{h})$, and

Pr is process productivity (ton).

The unit price of harvesting one ton wheat (HOTW) for different harvesting systems was derived from relating Equation (5) to the purchase price of combines on the market with varying drum widths (Agrimach, 2002). The parameters of calculated costs are found as shown in table (3);

Table (3): Implement service costs

\begin{tabular}{|l||c|c|c|c|}
\hline \multirow{2}{*}{$\begin{array}{l}\text { Items } \\
\text { Type of machines }\end{array}$} & \multirow{2}{*}{$\begin{array}{c}\text { Purchase price } \\
(\text { LE) }\end{array}$} & Year & $\mathrm{H}$ & \multirow{2}{*}{$\begin{array}{c}\text { Live time } \\
\text { maint. and repairs } \\
\text { machine price, } \%\end{array}$} \\
\hline Tractor 45 hp & 60000 & 10 & 10000 & 90 \\
\hline $\begin{array}{l}\text { Reaper tractor } \\
\text { mounted }\end{array}$ & 7000 & 10 & 1500 & 80 \\
\hline Thresher & 10000 & 10 & 1500 & 65 \\
\hline Combine & 300000 & 10 & 2500 & 60 \\
\hline
\end{tabular}




\section{RESULTS AN D DISCUSSION}

\section{The machine capacity and labour requirement}

It is important that unproductive work be minimized. The proportion of the productive time during the operational cycle is expressed as the field efficiency factor (FE). The "FE" was estimated for the ranges of capacities measured on the farm studies. Average results from these estimations were used for the machinery sizing scenario (table 4). The data in table (4) indicated that the field efficiency decreased with increasing the harvesting speed for all different harvesting systems. Whereas, the losses time of harvesting is inversely proportional with operation speed. Compared the "reaper + thresher" harvesting system with the manual system, indicated the closed differences between them. The operation times per fed. recorded $0.385 ; 0.357 ; 6.65$ and $12.15 \mathrm{~h} /$ fed for combine with tank, combine with bagger, "reaper + thresher" and "manual + thresher" systems respectively (table 5).

The required of the labour number for three systems under studies are tabulated in table (5). There were 5; 2; 15 and 23 labour per harvesting systems for combine with tank, combine with bagger, "reaper + thresher" and "manual + thresher" systems respectively. Also, the table (5) includes the total manual energy required per ton "kW.h/ton" to harvest one fed. From table, the total energy for combine harvester recorded $0.8 \mathrm{~kW} . \mathrm{h} / \mathrm{fed}$ while; it was about $6.73 \mathrm{~kW} . \mathrm{h} / \mathrm{fed}$ for the manual system. Regarding to the purchase price of combine machine, the power per unite area is very small but the inertia cost is very height.

\section{Energy requirements}

The energy requirements for different harvesting systems were calculated for manual (human energy) and mechanical. The human energy is tabulated in table 4. Which, it indicated that the human energy per fed for the third system is about $6.42 \mathrm{~kW} . \mathrm{h}$ whereas for the first system is about $0.144 \mathrm{~kW} . \mathrm{h}$ per fed. The mechanical energy is illustrated in table (6). From table, it may be notes that, the mechanical energy for the third harvesting systems is very low comparative with the first one. But, the total energy indicated the inverse of the above results. 
Table (4): The field capacity and field efficiency

\begin{tabular}{|c|c|c|c|c|c|c|c|c|c|}
\hline \multicolumn{3}{|c|}{$\begin{array}{r}\text { Harvesting } \\
\text { methods }\end{array}$} & $\begin{array}{c}\text { Operating } \\
\text { time } \\
\text { h/fed }\end{array}$ & \begin{tabular}{|l} 
Turn \\
time \\
$\mathrm{h} / \mathrm{fed}$
\end{tabular} & $\begin{array}{l}\text { Empt. } \\
\text { Time } \\
\text { h/fed }\end{array}$ & $\begin{array}{l}\text { Total } \\
\text { time } \\
\mathrm{h} / \mathrm{fed}\end{array}$ & $\begin{array}{c}\text { Act. Field } \\
\text { capacity } \\
\text { fed/h }\end{array}$ & $\begin{array}{l}\text { Theo. } \\
\text { F.C } \\
\text { fed/h }\end{array}$ & $\begin{array}{c}\text { Field } \\
\text { efficiency } \\
\%\end{array}$ \\
\hline \multirow{6}{*}{ Comb. } & \multirow[t]{3}{*}{$\operatorname{tank}$} & 1.96 & 0.582 & 0.072 & -- & 0.654 & 1.529 & 1.99 & 76.83 \\
\hline & & 3.19 & 0.358 & 0.072 & -- & 0.430 & 232 & 3.23 & 71.82 \\
\hline & & 4.0 & 0.285 & 0.072 & -- & 0.357 & 2.8 & 4.06 & 68.99 \\
\hline & \multirow[t]{3}{*}{ bagger } & 1.99 & 0.568 & 0.068 & 0.038 & 0.674 & 1.4 & 2.02 & 73.51 \\
\hline & & 3.31 & 0.340 & 0.068 & 0.038 & 0.446 & 2.2 & 3.36 & 66.58 \\
\hline & & 4.12 & 0.279 & 0.068 & 0.038 & 0.385 & 2.5 & 4.11 & 63.24 \\
\hline \multirow{3}{*}{\multicolumn{2}{|c|}{ Reaper }} & 3.10 & 1.04 & 0.1 & - & 1.14 & 0.880 & 1.1 & 75.00 \\
\hline & & 4.20 & 0.80 & 0.1 & -- & \begin{tabular}{|l|}
0.90 \\
\end{tabular} & 1.11 & 1.53 & 72.42 \\
\hline & & 4.90 & 0.663 & 0.1 & -- & 0.763 & 1.31 & 1.86 & 70.31 \\
\hline \multicolumn{3}{|c|}{ Manual } & 3.15 & -- & -- & 3.15 & 0.317 & ב--- & ב----- \\
\hline
\end{tabular}

Table (5): The manual energy requirements "kW.h/fed"

\begin{tabular}{|c|c|c|c|c|c|c|}
\hline $\begin{array}{c}\text { Harvesting } \\
\text { systems }\end{array}$ & Items & $\begin{array}{l}\text { No. of } \\
\text { labour }\end{array}$ & $\begin{array}{c}\text { Total } \\
\text { No }\end{array}$ & $\begin{array}{c}\text { Manual } \\
\text { energy } \\
\mathrm{kW}\end{array}$ & $\begin{array}{c}\text { Total } \\
\text { manual } \\
\text { time } \\
\mathrm{h} / \mathrm{fed}\end{array}$ & $\begin{array}{c}\text { Total manual } \\
\text { energy } \\
\mathrm{kW} \cdot \mathrm{h} / \mathrm{fed}\end{array}$ \\
\hline \multirow{2}{*}{$\begin{array}{c}\text { Combine } \\
(\text { system-1) }\end{array}$} & Bagger & 5 & 5 & 0.373 & 0.385 & 0.144 \\
\hline & Tank & 2 & 2 & 0.149 & 0.357 & 0.053 \\
\hline \multirow{2}{*}{$\begin{array}{c}\begin{array}{c}\text { Reaper }+ \\
\text { threshing } \\
(\text { system-2) }\end{array} \\
\end{array}$} & $\begin{array}{l}\text { Collect } \\
\text { yield }\end{array}$ & 8 & \multirow[t]{2}{*}{15} & 0.597 & 3.50 & 2.089 \\
\hline & Threshing & 7 & & 0.522 & 3.15 & 1.644 \\
\hline \multirow{3}{*}{$\begin{array}{c}\text { Manual + } \\
\text { thrusting } \\
\text { (system-3) }\end{array}$} & Cutting & 8 & \multirow{3}{*}{23} & 0.597 & 5.00 & 2.985 \\
\hline & $\begin{array}{l}\text { Collect } \\
\text { yield }\end{array}$ & 6 & & 0.448 & 4.00 & 1.792 \\
\hline & Threshing & 7 & & 0.522 & 3.15 & 1.644 \\
\hline
\end{tabular}


Table (6): The mechanical energy "kW h/fed" for three systems

\begin{tabular}{|c|c|c|c|c|c|c|c|}
\hline \multicolumn{3}{|c|}{$\begin{array}{ll}\text { Speed } & \begin{array}{c}\text { Harvesting } \\
\text { methods }\end{array} \\
\end{array}$} & $\begin{array}{l}\text { Total } \\
\text { time } \\
\text { h/fed }\end{array}$ & $\begin{array}{l}\text { Act. fuel } \\
\text { consumed } \\
\text { L/h }\end{array}$ & $\begin{array}{l}\text { Mechanical } \\
\text { power } \\
\text { kW }\end{array}$ & $\begin{array}{c}\text { Mechanical } \\
\text { energy } \\
\text { kWh/fed }\end{array}$ & $\begin{array}{c}\text { Total } \\
\text { energy } \\
\text { kW.h/fed }\end{array}$ \\
\hline \multirow{6}{*}{$\begin{array}{c}\text { Combine } \\
\text { (system- } \\
1)\end{array}$} & \multirow{3}{*}{$\operatorname{tank}$} & $\overline{c 1.96}$ & 0.654 & $\begin{array}{l}10.09 \\
\end{array}$ & $\begin{array}{ll}101.18 \\
\end{array}$ & 466.17 & \\
\hline & & 3.19 & 0.430 & 11.59 & 116.22 & 49.97 & \\
\hline & & 4.0 & 0.357 & 12.25 & 122.84 & 43.85 & 43.994 \\
\hline & \multirow{3}{*}{ bagger } & 1.99 & 0.674 & 12.70 & 127.36 & 85.84 & \\
\hline & & 3.31 & 0.446 & 13.55 & 135.88 & 60.60 & \\
\hline & & 4.12 & 0.385 & 13.95 & 139.89 & 53.86 & 53.913 \\
\hline \multirow{4}{*}{\multicolumn{2}{|c|}{$\begin{array}{c}\text { Reaper + } \\
\text { Threshing } \\
\text { (system-1) }\end{array}$}} & 3.10 & 1.14 & 4.20 & 42.12 & 48.02 & $\begin{array}{l}50.109 \\
\end{array}$ \\
\hline & & 4.20 & 0.90 & 4.70 & 47.13 & 42.42 & 44.064 \\
\hline & & 4.90 & 0.763 & 5.00 & 50.14 & 38.26 & 41.245 \\
\hline & & ----- & 3.15 & 4.53 & 45.43 & 143.10 & 144.892 \\
\hline \multicolumn{2}{|c|}{$\begin{array}{c}\text { Manual +threshing } \\
\text { (system-1) }\end{array}$} & ------ & 3.15 & 4.53 & 45.43 & 143.10 & 144.744 \\
\hline
\end{tabular}

\section{The wheat harvesting machinery costs}

The costs of labour during wheat harvesting under different systems is calculated in table (7) while the costs for one ton of wheat yield (k.W h/ton - and LE/ton) is found in table (8). The cost of human were $0.334 ; 0.057$; 7.25 and $19.52 \mathrm{kWh} /$ ton per harvesting systems for combine with tank, combine with bagger, "reaper + thresher" and "manual + thresher" systems respectively. While, the total costs required per ton "LE/ton" were about 88.57; 87.25; 82.4 and 110.25 LE/ton for harvesting systems for combine with tank, combine with bagger, "reaper + thresher" and "manual + thresher" systems respectively.

Table (7): The costs of labour during wheat harvesting under different systems

\begin{tabular}{|c|c|c|c|c|c|}
\hline $\begin{array}{l}\text { Harvesting } \\
\text { systems }\end{array}$ & Items & $\begin{array}{c}\text { Daily } \\
\text { hair } \\
\text { LE/day }\end{array}$ & $\begin{array}{c}\text { Total } \\
\text { daily hair } \\
\text { LE/day }\end{array}$ & $\begin{array}{l}\text { Total } \\
\text { time } \\
\text { h/fed }\end{array}$ & $\begin{array}{c}\begin{array}{c}\text { Total } \\
\text { energy } \\
\text { kW.h/ton }\end{array} \\
\end{array}$ \\
\hline \multirow{2}{*}{$\begin{array}{l}\text { Combine } \\
\text { (system-1) }\end{array}$} & Bagger & 15.0 & 75.0 & 2.15 & 0.344 \\
\hline & Tank & 15.0 & 30.0 & 0.90 & 0.0574 \\
\hline \multirow{2}{*}{$\begin{array}{l}\text { Reaper + } \\
\text { threshing } \\
\text { (system-2) }\end{array}$} & $\begin{array}{l}\text { Collect } \\
\text { yield }\end{array}$ & 15.0 & 120.0 & 9.10 & 2.329 \\
\hline & Threshing & 15.0 & 105.0 & 22.00 & 4.923 \\
\hline \multirow{3}{*}{$\begin{array}{c}\text { Manual + } \\
\text { thrusting } \\
\text { (system-3) }\end{array}$} & Cutting & 15.0 & 120.0 & 40.00 & 10.238 \\
\hline & $\begin{array}{l}\text { Collect } \\
\text { yield }\end{array}$ & 15.0 & 90.0 & 24.00 & 4.609 \\
\hline & Threshing & 15.0 & 105.0 & 22.00 & 4.923 \\
\hline
\end{tabular}


Table (8): The costs and energy requirement for one unite of the yield (k.w h/ton - and LE/ton)

\begin{tabular}{|c|c|c|c|c|c|c|c|c|c|c|}
\hline \multirow{2}{*}{\multicolumn{2}{|c|}{$\begin{array}{l}\text { harvesting } \\
\text { methods }\end{array}$}} & \multirow{3}{*}{$\begin{array}{c}\begin{array}{c}\text { Machine } \\
\text { costs } \\
\text { L.E/h }\end{array} \\
164.35 \\
\end{array}$} & \multirow{3}{*}{$\begin{array}{c}\text { Daily } \\
\text { Hire } \\
\text { L E/h }\end{array}$} & \multirow{3}{*}{$\begin{array}{c}\begin{array}{c}\text { total } \\
\text { costs } L \\
\mathrm{E} / \mathrm{h}\end{array} \\
206.37\end{array}$} & \multicolumn{3}{|c|}{$\mathrm{K} w \mathrm{~h} / \mathrm{fed}$} & \multirow{3}{*}{$\begin{array}{c}\begin{array}{c}\text { Total } \\
\text { time } \\
\mathrm{h} / \mathrm{fed}\end{array} \\
0.357\end{array}$} & \multicolumn{2}{|c|}{$\begin{array}{c}\text { The total costs of } \\
\text { the yield }\end{array}$} \\
\hline & & & & & $\begin{array}{c}\text { Manu } \\
\text { Energy }\end{array}$ & $\begin{array}{l}\text { mech. } \\
\text { energy }\end{array}$ & $\begin{array}{c}\text { Total } \\
\text { energy }\end{array}$ & & $\begin{array}{c}\mathrm{kw} \\
\mathrm{h} / \mathrm{ton}\end{array}$ & LE/ton \\
\hline \multirow{3}{*}{$\begin{array}{r}\text { Combine } \\
\text { (system-1) }\end{array}$} & Tank & & & & 0.050 & 43.85 & 43.90 & & 18.84 & 88.476 \\
\hline & bagger & 164.35 & 38.96 & 203.31 & 0.140 & 53.86 & 54.00 & 0.385 & 23.18 & 87.164 \\
\hline & Total & & & & & & & & & \\
\hline \multirow{3}{*}{\begin{tabular}{|c} 
Reaper + \\
threshing \\
(system-2)
\end{tabular}} & reaper & 32.90 & 19.66 & 52.56 & 2.089 & 38.26 & 40.349 & 0.763 & 17.32 & 22.534 \\
\hline & thresher & 31.55 & 4.775 & 36.325 & 1.644 & 143.10 & 144.744 & 3.15 & 62.12 & 15.573 \\
\hline & Total & 64.45 & 24.435 & 88.885 & & 181.36 & & & & 38.107 \\
\hline \multirow{3}{*}{$\begin{array}{c}\text { Manual + } \\
\text { thrusting } \\
\text { (system-3) }\end{array}$} & manual & -- & 192.00 & 192.00 & 4.777 & -- & 4.777 & 64.00 & 2.05 & 82.315 \\
\hline & thresher & 31.55 & 33.33 & 64.88 & 1.644 & 143.10 & 144.744 & 3.15 & 62.12 & 27.816 \\
\hline & Total & 31.55 & 36.33 & 67.88 & & 143.10 & & & & 110.131 \\
\hline
\end{tabular}

\section{REFERENCES}

Abd El-Mageed, H.N., M.H. Ramadan and M.M. Ibrahim (1987). A mathematical model for predicting optimum power and machinery sizes in a three year crop rotation in Egypt. Misr, J. Agric. Eng. 4(2): 134-148.

Agrimach (2002). Agrimach Multimedia: The International Source for Agricultural Machinery. European Commission - DG XIII Programme Info2000. Regione Emilia-Romagna.

Atzema, A. J. (1990). Moisture distribution within a maize crop due to dew. Netherlands Journal of Agricultural Sciences 38:117-129.

Atzema, A. J. (1994). From the weather forecast to the prognostic moisture content of agricultural crops. Thesis, Wageningen Agricultural University, The Netherlands.

Audsley, E. (1984). Use of weather uncertainty, compaction and timeliness in the selection of optimum machinery for autumn field work: A dynamic programme. Journal of Agricultural Engineering Research 29(2):141-149.

Audsley, E. and D. S. Boyce (1974). A method of minimizing the costs of combine-harvesting and high temperature grain drying. Journal of Agricultural Engineering Research 19(2):173-188. 
Bender, D. A., D. E. Kline and B. A. McCarl (1990). Postoptimal linearprogramming analysis of farm machinery. Transactions of the ASAE 33:15-20.

Chancellor, W.J. (1981). Substituting information for energy in agriculture. Trans. ASAE 24(4): 802-807.

De Toro A., A. \& Hansson, P.A. (2004b). Analysis of field machinery performance based on daily soil workability status using discrete event simulation or on average workday probability. Agricultural Systems 79, 109-129.

Edward, W. and M. Boehije (1980). Machinery selection considering timeliness losses. Trans. Of the ASAE 23: 810-815.

Ekman, S. (2000). Tillage system selection: a mathematical programming model incorporating weather variability. Journal of Agricultural Engineering Research 77:267-276.

Elrick, J. D. (1982). How to choose and use combines. Publication No. 88. Edinburgh: East of Scotland College of Agriculture.

Goense, D. (1987). Mechanised Farming in the Humid Tropics with Special Reference to Soil Tillage, Workability and Timeliness of Farm Operations: A Case Study for Zanderij Area of Suriname. Wageningen, the Netherlands: Agricultural University of Wageningen.

Have, H. (1991). Planning and Control in Agricultural Field Mechanisation. Frederiksberg C, Denmark: The Royal Veterinary and Agricultural University.

Henrichsmeyer, F., J. Ohls and K. Winter (1995). Leistung und Kosten von Arbeitsverfahren in Grossbetrieben (Work requirement and costs on large farms). Landtechnik 50:296-297.

Hunt, D. (1995). Farm Power and Machinery Management. Ames, Iowa: Iowa State University Press.

Ismail, Z.E.; M.M. Ibrahim and S.A. Embaby (2009). Economic evaluation and selection of farm machinery. Misr J. Ag. Eng., 26(4): 746-757 
Jannot, P. and D. Cairol (1994). Linear programming as an aid to decisionmaking for investments in farm equipment for arable farms. Journal of Agricultural Engineering Research 59:173-179.

Lundin, G. and S. Claesson (1985). Skõrdetrõskning (Combine harvesting). Publication 409. Uppsala, Sweden: Swedish Institute of Agricultural Engineering. Lyngby, Denmark.

Nilsson, B. (1972). Optimering av maskinkapacitet vid spanmålsskord. Rapport nr. 11. Uppsala, Sweden: Institutionen för Arbetsmetodik och Teknik, Lantbrukshögskolan.

Nilsson, B. (1987). Planering av arbets- och maskinsystem- resultat och erfarenheter. Uppsala: Department of Agricultural Engineering, Swedish University of Agricultural Sciences. (Institutionsmed de lande 87:03).

Parmar, R. S., R. W. McClendon and W. D. Potter (1996). Farm machinery selection using simulation and genetic algorithms. Transactions of the ASAE 39(5):1905-1909.

Philips, P. R. and J. R. O'Callaghan (1974). Cereal harvesting: A mathematical model. Journal of Agricultural Engineering Research 19:415-433.

Soerensen, C.G. (2003). Workability and Machinery Sizing for Combine Harvesting. Agricultural Engineering International: the CIGR Journal of Scientific Research and Development. Manuscript PM 03003 Vol V.

Srivastava, A.K., Goering, C.E., Rohrbach, R.P. \& Buckmaster, D.R. (2006). Engineering Principles of Agricultural Machines. 2nd edition. St. Joseph, Michigan, USA: American Society of Agricultural and Biological Engineers.

Tsai, Y. J., J. W. Jones and J. W. Mishoe (1987). Optimizing multiple cropping systems: A systems approach. Transactions of the ASAE 30(6):1554-1561.

Witney, B. (1995). Choosing and Using Farm Machines. UK: Longman Scientific and Technical. WMO. 1974. Manual on Codes. Vol I. World Meteorological Organization, No. 306. Geneva, Switzerland: WMO. 


\section{الملخص العربي \\ الأداء التثغيلى لآلات حصاد القمح

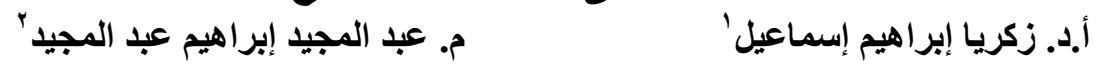

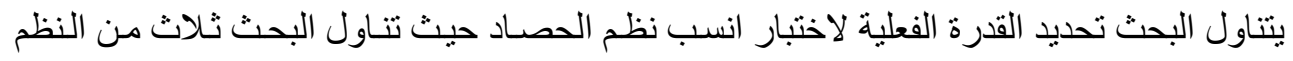

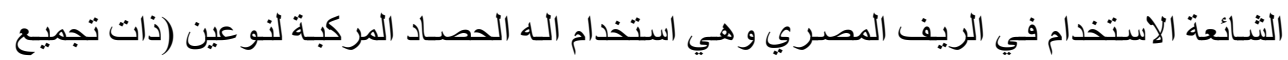

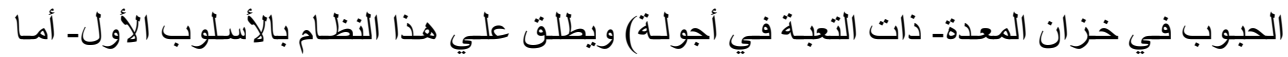

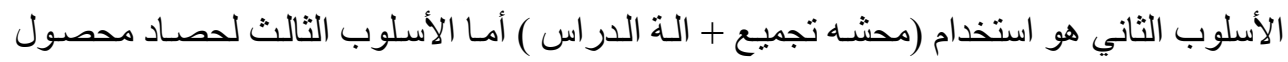



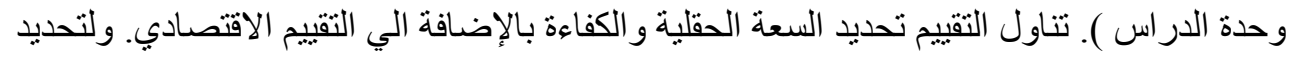



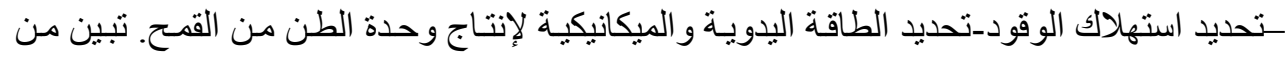

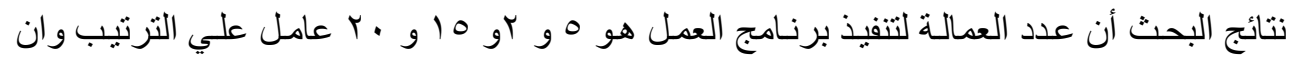

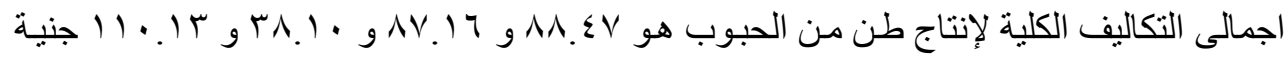
مصري لكل واحد طن من الحبوب.

1 أستاذ تكنولوجيا القوى والآلات الزر اعية ـ قسم الهندسة الزر اعية ـ كلية الزر اعة اعنة - جامعة المنصورة.



